\title{
THE GARDEN AS THE PLACE OF THE ENCOUNTER OF GOD AND ISRAEL AND ITS PLACE IN (HI-)STORY AND SPACE: SONG 4:16-5:1 IN THE RECEPTION OF RABBINIC MIDRASHIM
}

Johanna Erzberger

University of Pretoria

69B Anderson Street

Brooklyn, Pretoria, 0181

South Africa

E-mail: johannaerzberger@web.de

(Received 20/10/2015; accepted 23/01/2016)

\begin{abstract}
Song Rab. 4:16-5:1, Num. Rab. 13, Pesiq. Rab. 5, and Lev. Rab. 9, which offer interpretations of Song 4:16-5:1, are to a high degree made up of the same fixed text passages. They are, however, characterised by different selections, different versions, and different ways in which they organise the shared material by means of different models of Israel's remembered history, which serve as "hypertexts". Differing interpretations of Song 4:16-5:1, and especially the understanding of the significance of the garden in the Song, are linked with the midrashim's differing interpretations of Israel's remembered history. The way in which identical material is used by these different midrashim to make different statements makes them a good example of the handling of traditional material by haggadic rabbinic midrashim.
\end{abstract}

\section{INTRODUCTION}

Definitions of "midrash" are countless. ${ }^{1}$ The following analysis of the reception of Song 4:16-5:1 in rabbinic midrashim refers to texts that are commonly called "haggadic" (Boyarin 1990:VIII; Teugels 1998:47). The exclusion of targumic and

1 From Shinan's and Zakovitch's point of view, all interpretation of scripture is midrash. From this perspective, Michelangelo's Moses is midrash (Shinan and Zakovitch 1986:258). Such a broad definition is not generally helpful. Already in 1967, Wright expressed his concern: "The word as used currently in biblical studies is approaching the point where it is no longer meaningful" (Wright 1967:22.) For an overview, see Erzberger (2010:14-15). Nevertheless, it is not easy to delimit what constitutes midrash, and there may be countless ways to do so. 
talmudic literature and of halakhic midrashim and the kabbalah is a pragmatic decision which, however, seems justifiable, since the texts analysed in this study are more similar to one another in method and content than those excluded.

Haggadic rabbinic midrashim are to a high degree made up of smaller text passages that can also be found in other haggadic rabbinic midrashim. ${ }^{2}$ Those passages that I call "traditional pieces" (fixed textual entities made up of conventional material) (Erzberger 2010:40) had a prior existence of some kind before being placed in their present contexts. Variations between the versions of a given traditional piece that appears in different midrashim can be shown to serve the contexts in which it has been placed in a meaningful way. Those contexts consequently prove to be meaningful on their own.

It has often been noted that rabbinic texts interpret biblical texts in light of other biblical texts (Porton 1985:9.171; Kugel 1990:167-190; Stemberger 1992:235; Samely 2007:83). Boyarin was the first to use the term "intertextuality" to describe the way in which rabbinic texts read biblical texts in light of other biblical texts, drawing on basic elements of different concepts of intertextuality without creating a coherent theory of intertextuality on his own:

This concept [of intertextuality] has several accepted senses, three of which are important in my account of Midrash. The first is that the text is always made of a mosaic of conscious and unconscious citation of earlier discourse. The second is that texts may be dialogical in naturecontesting their own assertions as an essential part of the structure of their discourse - and that the Bible is a preeminent example of such a text. The third is that there are cultural codes, again either conscious or

2 There is a broad consensus to refer to these smaller text passages as meaningful (cf. Goldberg 1990, Kugel 1986). According to Stern, Samely and Boyarin small text passages are part of a discourse that transgresses the individual document (cf. Stern 1996, Samely 2007, Boyarin 1990). Midrashic documents are sometimes referred to as collections of these smaller passages (cf. Stemberger 1992, Bakhos 2006). Neusner postulates a characteristic program and style of each midrashic work ("documentary reading"). However, this characteristic program and style seems to be limited to the specific selection of traditional text passages in a given midrashic work. Their specific arrangement and form are not taken into account (cf. Neusner 1993, 1998). 


\section{unconscious, which both constrain and allow the production (not} creation) of new texts within the culture; these codes may be identified with the ideology of the culture, which is made up of the assumptions that people in the culture automatically make about what may or may not be true and possible, about what is natural in nature and history (Boyarin 1990:12; emphasis mine).

The possibilities for establishing intertextual references are limited by cultural codes. These cultural codes include the selection of texts that are considered relevant as well as the selection of texts that are understood to refer to each other and the mode in which they are thought to do so.

By interlinking biblical intertexts, midrashim create structures ("hypertexts") that define the mode in which these texts are interlinked. The hypertexts describe relations in time or space and even causal relations. In contrast to Boyarin, I do not think the midrashim decontextualise the biblical verses they quote (see Boyarin 1990:23). The extent to which the context of any quoted verse is alluded to, however, can only be judged by the extent to which the midrash responds to it. The newly created hypertexts do not replace textual and narrative structures provided by the immediate context of the quoted verses. They rather claim a structure underlying the biblical tradition that relates even texts that are not obviously related.

By recontextualising conventional intertextual references and even fixed textual entities in which these conventional intertextual references are embedded, different midrashim create different hypertexts and make different propositions. I will analyse the interpretation of Song 4:16-5:1 by Song. Rab. in some detail, concentrating on the hypertext that it creates. I will then demonstrate that the same textual material is used in other midrashim, such as Lev. Rab., Num. Rab., and Pesiq. Rab., to create varying hypertexts, and I will analyse how varying hypertexts exhibit different perspectives on Song 4:16-5:1. 


\section{THE INTERPRETATION OF SONG 4:16-5:1 IN SONG. RAB.}

Discussing the contextualisation of fixed textual entities made up of conventional material raises the question of how to delimit the relevant context, if it is not considered to be the entire rabbinic work. So-called homiletic midrashim consist of several individual homilies that are identifiable by their recurrent structure. ${ }^{3}$ Midrashim that interpret a whole biblical book verse by verse might be subdivided into textual units that the midrash considers recognisable within the biblical book and makes recognisable to the reader.

The subdivisions in Song 4-5 that are recognised by Song. Rab. are mirrored by the alternating topics that the interpretation focuses on. The perceived structure of the biblical text largely accords with that of modern exegesis. ${ }^{4}$ The description of the woman's physical attractiveness in Song 4:1-7 is read as a description of Israel. 4:811 refers to Israel, who is depicted as God's bride, returning from exile. The interpretation of 4:12-5:7 focuses on the garden and the house as the locations of either a successful or a failed encounter. Within 4:12-5:7, 4:16-5:1 constitute a selfcontained unit, which focuses on the garden. The woman's description of the man's physical attractiveness in 5:8-16 is read as a description of the law, which is understood as God's gift to Israel.

In the perception of Song. Rab., 4:16-5:1 constitutes a self-contained unit, the interpretation of which is built on these verses' dialogue structure:

\section{Song. Rab. 4:16-5:1}

Song 4:16ab the offerings of the sons of Noah

Song 4:16cd the reconciliation of the winds in the future

Song 4:16e the groom enters the bride's chamber only after the bride's consent

3 Homilies start with several small textual entities (petichot) building on the same initial verse, continue with an interpretation focusing on the succeeding verses, and close with a statement referring to an eschatological future (chatima). For the description of homilies, see Goldberg (1985:86), Stern (1996:55-72).

4 See Keel (1986:29-194):4:1-7; 4:8; 4:9-11; 4:12-5:1; 5:2-8; 5:9-16; Zakovitch (2004:180-229):4:1-7; 4:8-11; 4:12-5:1; 5:2-6:3; Schwienhorst-Schönberger (2015:109132):4:1-7; 4:8-9; 4:10-11; 4:12-15; 4:16-5:1; 5:2-8; 5:9-16. While modern exegesis reads $5: 8-16$, the woman addressing the daughters of Jerusalem, as a continuation of 5:2-7, the woman's search for her beloved, the midrash observes a closer connection between 4:16-5:1 and 5:2-7, which focuses on the locations of a successful or failed encounter. 


\begin{tabular}{|ll|}
\hline Song 5:1a & $\begin{array}{l}\text { the ascent and descent of the Shekinah } \\
\text { mashal of the queen, who after having been dismissed agrees to return to her } \\
\text { husband only after having received a gift }\end{array}$ \\
Song 5:1bcd & spices (b); sacrifices (cd) \\
Song 5:1e & Moses \& Aaron - Nadab \& Abihu \\
Song 5:1e & the acceptance of the princes' illegitimate sacrifices \\
Song 5:1e & mashal of the king's banquet
\end{tabular}

The interpretation starts with a small textual entity, made up of conventional material also found in other midrashim, focusing on the question of whether or not שלמים, peace offerings, were possible before the giving of Torah at Sinai:

עורי צפון ובואי תימן, ר' אלעזר ורבי יוסי ברבי חנינא, רבי אלעזר

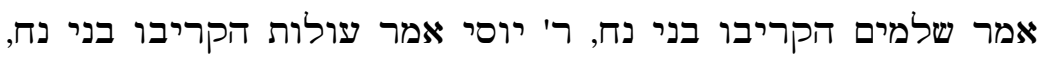

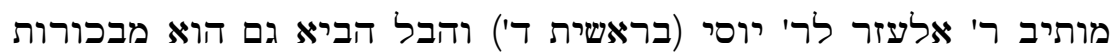

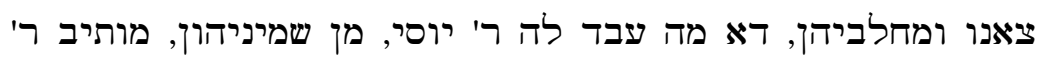

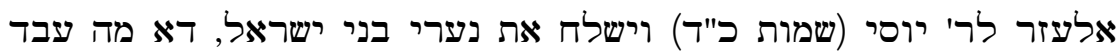

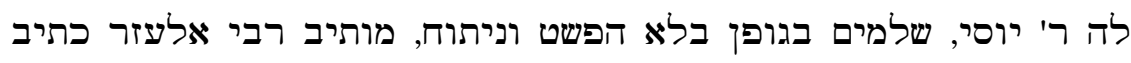

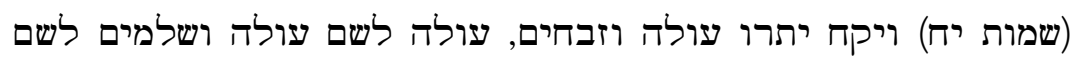

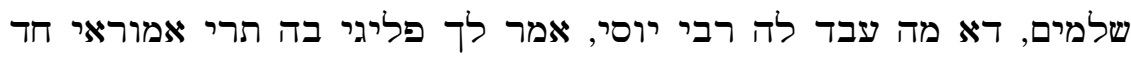

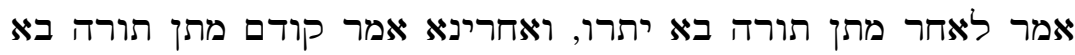

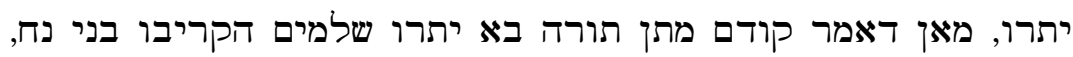

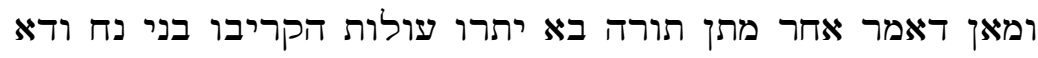

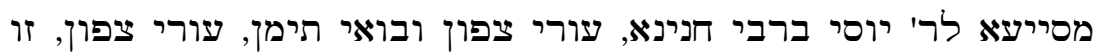

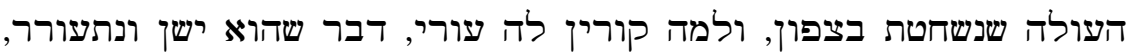

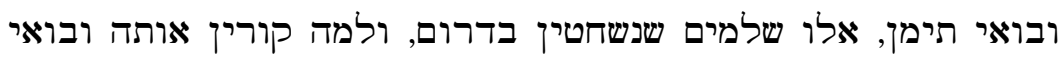

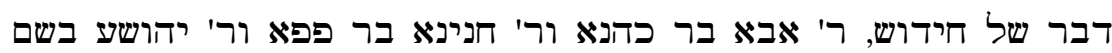

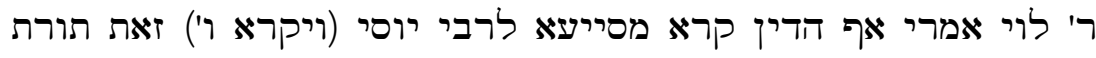

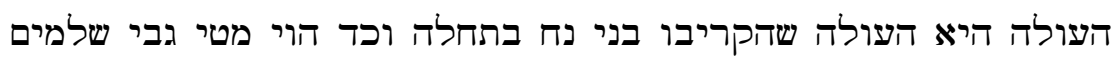

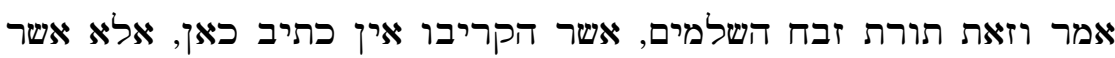

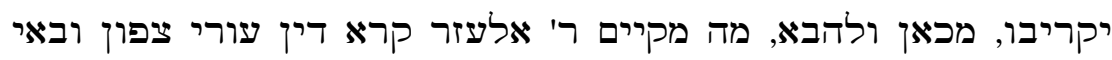

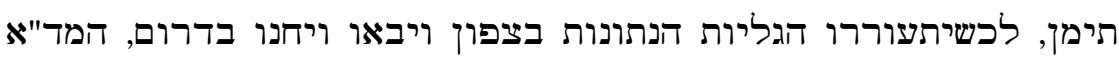

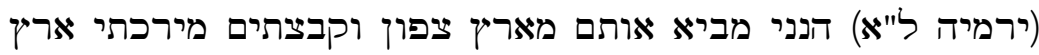

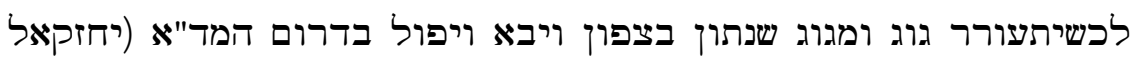


לט) ושבבתיך וששאתיך והעליתיך, לכשיתעורר מלך המשיח שנתון

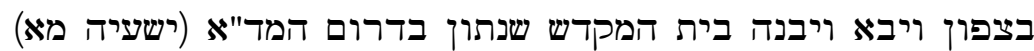

העירותי מצפון ויאת

(Bar'Ilan University [ed.], Responsa Project. Version 22+, Tel Aviv 2014.)

'Awake, north wind, and come, south wind' (Song 4:16). R. Eleazar and R. Jose b. R. Hanina. R. Eleazar said: The children of Noah offered peace offerings; R. Jose said: The children of Noah offered burnt offerings. R. Eleazar answered R. Jose: And Abel for his part brought of the firstlings of his flock, their fat portions (Gen 4:4). What did R. Jose make of this? Of their fat ones. R. Eleazar answered R. Jose: "And he sent the young men of the children of Israel" (Exod 24:5). What did R. Jose make of this? Peace offerings (shelamim), of the entire body, without skinning or cutting up. R. Eleazar answered: It is written: "And Jethro ... brought a burnt offering and sacrifices" (Exod 18:12). A burnt offering stands there for a burnt offering, and peace offerings stand there for peace offerings. What did R. Jose make of this? It tells you: On this two Amoraim differ in opinion. One says that Jethro came after the giving of Torah and the other says that Jethro came before the giving of Torah. The one who says that Jethro came before the giving of Torah: the children of Noah offered peace offerings. And the one who says that Jethro came after the giving of Torah: the children of Noah offered burnt offerings. This is a support for R. Jose b. R. Hanina: "Awake, north wind, and come, south wind" (Song 4:16). "Awake, north wind": this is the burnt offering, which is slaughtered in the north. And why do they call it "awake"? Something that was asleep and is awakened. "And come, south wind": these are the peace offerings, which are slaughtered in the south. And why do they call it "come"? Something new. R. Abba b. Kahana and R. Hanina b. Papa and R. Joshua in the name of R. Levi say: The following verse is also a support for R. Jose: "This is the Torah of the burnt offering" (Lev 6:2); that is the burnt-offering that the children of Noah offered in the 
beginning. But when it comes to the peace offerings, it says: "And this is the Torah of the sacrifice of the peace offerings," about which is not written "which they did offer" but "which they will offer" (Lev 7:11), from now and for the future. What does R. Eleazar identify this verse with: "Awake, north wind, and come, south wind?" When the exiles who are given to the north are woken up and come and camp in the south, as you have said: "See, I am going to bring them from the land of the north, and gather them from the ends of the earth" (Jer 31:8). When Gog and Magog, who are given to the north, are woken up, and he will come and he will fall upon the south, as you have said: "And I will turn you around and I will lead you, and I will bring you up" (Ezek 39:2). When the king messiah, who is given to the north, is woken up and he will come and he will built the house of the sanctuary, which is given to the south, as you have said: "I have woken up from the north, and he has come" (Isa 41:25).

The textual entity has Rabbi Eliezer and Rabbi Jose bar Chanina discussing whether the offerings of the children of Noah were עולות, burnt offerings, or שלמים, peace offerings, by successively discussing the offerings of Abel in Gen 4, of the young men of Israel in Exod 24, and of Jethro in Exod 18. According to Rabbi Eliezer, the children of Noah offered שלמים. According to Rabbi Jose bar Chanina, they offered עולות. It is finally the timing of the offering of Jethro that determines the possibility of שלמים before the giving of Torah.

The quality of the offerings of Abel and the young men remains uncertain if judged only on the basis of the biblical texts that mention them. מבכרות in in Gen 4:4 can be understood according to Rabbi Eliezer as indicating the fat of the sacrificed animals. Abel would consequently be offering שלמים. It can also be understood according to Rabbi Jose bar Chanina, as indicating the fat animals of his flock. Abel would consequently be offering עולות.

The meaning of ויעלו עלת ויזבחו זבחים שלמים ליהוה in Exod 24:5 is equally ambiguous, according to the midrash. Rabbi Eliezer understands שלמים as 
plainly and simply indicating שלמים. Rabbi Jose bar Chanina reads שלם as meaning "entirely"/“totally"; the offering of an entire animal, however, would be an עולה. Consequently, the young men did not offer שלמים.

The midrash's position becomes clear in the course of its interpretation of Jethro's sacrifice according to Exod 18:12. Having heard about Israel's escape from Egypt, Jethro visits his son-in- law. After having confessed that the God of Israel is greater than all gods, Jethro prepares a sacrifice (ויקח ... עלה וזבחים לאלהים). The midrash identifies the שלמים as זבחים. If Jethro's offering took place before the revelation of Torah, in keeping with the chronology of the Bible, the children of Noah might have offered שלמים. If Jethro's offering took place after the revelation of the Torah, against the chronology of the Bible, the children of Noah would have to have offered עולות. The midrash, underlining its position by the order of its presentation and closing with Jethro's sacrifice, supports Rabbi Jose bar Chanina: Jethro came after the revelation of the Torah. Only the revelation of the Torah allows the offering of שלמים.

The interpretation of Song 4:16a, עורי צפון ובואי תימן, "Awake, north wind, and come, south wind," is cited as supporting Rabi Jose's position, which restricts the possibility of שלמים to after the giving of Torah. While verse 16aa (עורי צפון) is read as referring to the "waking" (עור) or "reintroduction" of the sacrifice taking place on the north side of the altar, the עולות, verse 16aß (ובואי תימן) is read as referring to the שלמים, considered to have taken place on the other side of the altar, which are supposed to "come" (בוא), or be first introduced.

The grammatical tenses used in Lev 6:2 and Lev 7:11, introducing legislative regulations concerning שלמים (Lev 6:11), שולות (Lev ) and thewise understood to highlight Rabbi Jose's position and the possibility of שלמים only after the giving of Torah. While Lev 6:2 forms a nominal phrase, understood as indicating something that already exists, Lev 7:12 has a yaqtal, which is read as referring to a future event.

Rabbi Jose's position is called into question with reference to Rabbi Eliezer, who identifies the "waking" of the north wind with future eschatological events. He does so with reference to the occurrence of צפון in Song 4:16 and several intertexts. By 
calling upon Song 4:16 and Jer 31:8, the "wakening" of the "north" is read as referring to the homecoming exiles in an eschatological future; by calling upon Song 4:16 and Ezek 39:2, it is read as referring to Gog's place of origin; and by calling upon Song 4:16 and Isa 41:25, it is finally read as referring to the coming of the messiah.

The midrash continues with an interpretation of 4:16b in light of Isa 43:6, attributed to Rabbi Huna, which is commenting on the preceding:

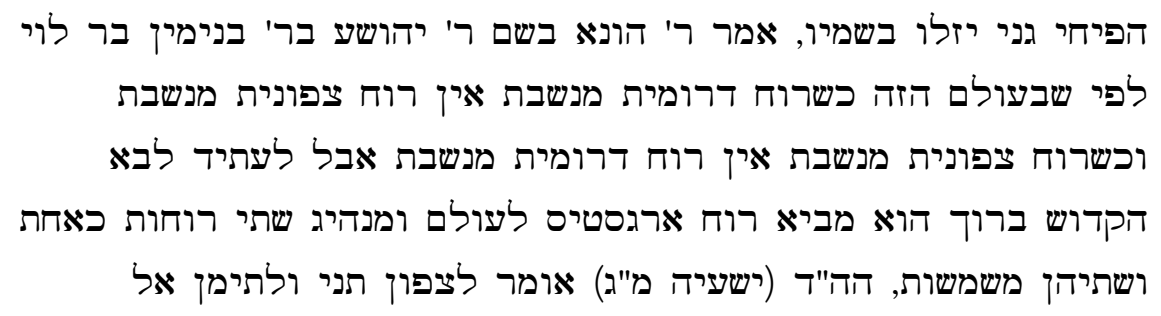

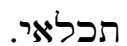

(Bar'Ilan University [ed.], Responsa Project. Version 22+, Tel Aviv 2014.) 'Blow upon my garden, its fragrance shall flow.' R. Huna said in the name of R. Joshua b. R. Benjamin b. Levi: As in this world when the south wind blows the north wind does not blow, and when the north wind blows the south wind does not blow. But in the time to come the Holy One, praised be he, will bring a wind, an argastes, on the world, and he drives the two winds like one, and the two will be in action, as it is written: 'I will say to the north, Give, and to the south, Do not hold back' (Isa 43:6).

In light of Isa 43:6, Song 4:16b (הפיחי גני יזלו בשמיו) is finally understood as implying the reconciliation of both winds and consequently the elimination of any distinction between a time before and a time after the giving of Torah in an eschatological future.

The interpretation of the following subsections of the biblical text builds on their dialogue structure and their interpretation as referring to the encounter of God and mankind at several significant moments in the remembered history. Song 4:16cd, the woman addressing her beloved and asking him to enter his garden and eat its fruit, is referred to as an example of good manners. The groom enters the bride's chamber 
only after the bride has given her consent. In the light of what follows, the groom's good manners become a reference to God's attitude toward Israel and mankind. In Song 5:1, the man answers the woman's invitation by taking up the wording of the preceding verse. The man answering the woman is read as God answering mankind. Through a change in vocalization, ${ }^{5}$ the garden of Song 4:16-5:1 is identified with the bride's chamber, and by reference to Gen 3:8 it is identified with the location of the initial encounter between God and man.

The following interpretation, which is attributed to R. Menahem, refers to the peculiar grammatical form of הלך hitpa'el in Gen. 3:8. The hitpa 'el not only signifies God entering the garden but also points to the subsequent withdrawal of God's presence.

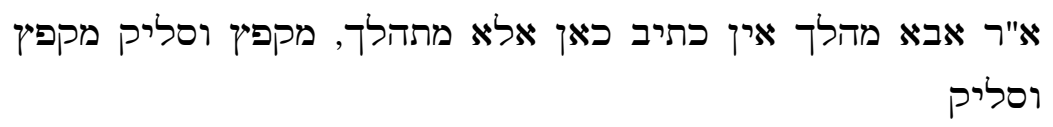

(Bar’Ilan University [ed.], Responsa Project. Version 22+, Tel Aviv 2014.)

R. Abba said: mehalek (piel) is not written here, but mithhalek (hitpael), leaping/skipping and going up, leaping/skipping and going up.

The history of God and mankind, starting with the initial encounter between God and mankind following creation in the Garden of Eden, is marked first by a gradual and successive withdrawal of God's presence, the Shekhinah, from among mankind, followed by its gradual and successive return, culminating in God's renewed final presence among Israel at the moment of the Sinai revelation. Seven evildoers, starting with the first man and ending with the Egyptians in the days of Abraham, ${ }^{6}$ gradually and successively banish God's presence from among mankind. Seven righteous people, forming an uninterrupted succession of generations from Abraham to Moses, gradually and successively bring God's presence back in the midst of Israel. In an interpretation of Ps 37:29, attributed to R. Isaac, the ארץ, which the righteous who

5 לגני ("into my garden") is read as לגנוני ("into my bride's chamber").

6 The parallel of the traditional piece in Num. Rab. 13 only refers to the Egyptians; the parallel in Pesiq. Rab. 5 has the Philistines in the days of Abimelech. Other versions of the same traditional piece, which will not be discussed in this article, include further variants. 
made the Shekinah return inherit, refers to both the earth and the land of Israel:

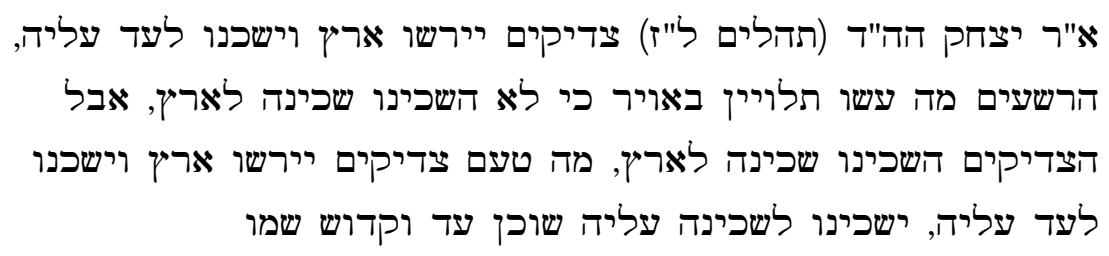

(Bar'Ilan University [ed.], Responsa Project. Version 22+, Tel Aviv 2014.)

R. Isaac said: This is what is written: 'The righteous will inherit the land and live in it forever' (Ps 37:29). What did the wicked do? They will be suspended in the empty space, because they did not make the Shekhinah live on the earth. But the righteous made the Shekhinah live on the earth. How do we know? The righteous will inherit the land and live in it forever. They will make the Shekhinah live on it, who lives forever, and holy is his name. (Isa 75:15)

The moment of the Shekhinah's final return is identified with the construction of the tabernacle:

ואימת שרת שכינה עליה ביום שהוקם המשכן, שנא' (במדבר ז') ויהי

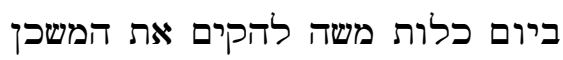
(Bar'Ilan University [ed.], Responsa Project. Version 22+, Tel Aviv 2014.)

When did the Shekhinah rest upon her [the earth]? On the day when the tabernacle was set up, as it is said, "And it came to pass on the day when Moses had finished setting up the tabernacle," etc. (Num 7:1)

The Shekhinah's final return is illustrated by a mashal centering on a king and a queen, attributed to R. Azariah:

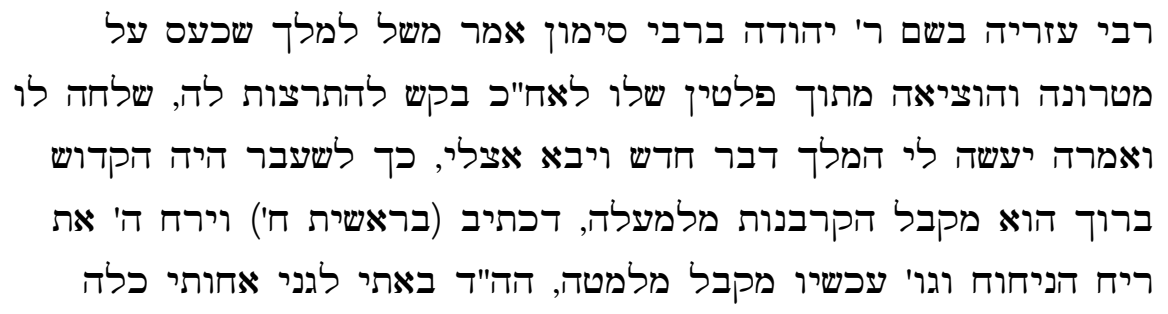


(Bar'Ilan University [ed.], Responsa Project. Version 22+, Tel Aviv 2014.)

R. Azariah said in the name of R. Judah b. R. Simon: Like a king who was angry with his queen, and he made her leave his palace. Afterward he wished to pardon her, and she sent to him and she said: "The king shall make something new for me, and he shall come to me." So formerly the Holy One, blessed be He, received sacrifices from above, as it is written: "And YHWH smelled the pleasing odor," etc. (Gen 8:21). Now he receives from below; this is what is written: "I came to my garden, my sister, my bride."

The queen, who after having been dismissed by her husband agrees to return to him only after having received a proof of his goodwill, is compared to Israel receiving the sanctuary.

The following subsections of verse 1 are interpreted as referring to different components of the cult. Moses and Aaron on the one hand and Nadab and Abihu on the other serve as examples of successful and failed encounters with God. An example of a successful encounter with God is the sacrifice of the princes in Num 7, which God accepts even though it transgresses several regulations concerning the offerings of an individual. A final series of three meshalim, the first of which illustrates God's acceptance of even irregular sacrifices with the story of a king's ignoring an insect that fell into the soup in order not to disturb the feast, ${ }^{7}$ refers to the final invitation to eat and drink in comparing God with a king who gives a banquet.

\section{The reconstruction of time and space in Song. Rab.}

In Song. Rab., the Song's garden represents different locations throughout Israel's history that reflect one another. The Song's garden represents the Garden of Eden as

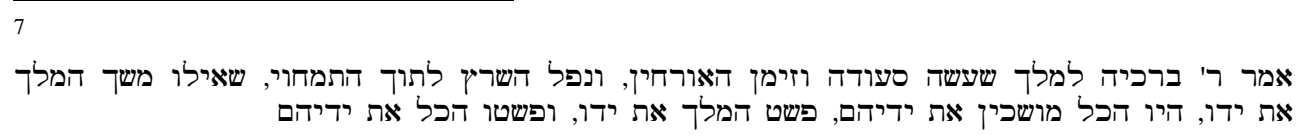

(Bar'Ilan University [ed.], Responsa Project. Version 22+, Tel Aviv 2014.)

"R. Berekhiah said: Like a king who made a feast and invited guests, and an unclean animal fell in the middle of the soup. If the king had withdrawn his hand, all would have withdrawn their hand. The king stretched out his hand, and all stretched out their hands." 
the place of the initial encounter of God and man. The garden refers to the sanctuary as the place of the presence of God among Israel. Within the fixed textual entity made up of traditional material that centres on the offerings of the sons of Noah, the garden also refers to the destination of the eschatological return of the exiles and the place of the sanctuary built by the messiah. This aspect is, however, not focused on by the general structure of the midrash.

The interpretation of Song 4:16 thus creates a temporal system of coordinates. The giving of the Torah marks the moment at which a history of disaster turns into a history of salvation. It is also marked by a change of perspective: According to Song. $R a b$., the disastrous history of the relationship between God and mankind is reversed in the history of the relationship between God and Israel. In Israel's history and the giving of Torah, God's history with mankind comes to a preliminary good ending, which foreshadows its final good ending in an eschatological future.

\section{THE INTERPRETATION OF SONG 4:16-5:1 IN OTHER MIDRASHIM}

Num. Rab. 13, Pesiq. Rab. 5, and Lev. Rab. 9 are to a great extent made up of the same material as Song. Rab. 4:16-5:1. However, the midrashim are characterized by different selections, different versions, and a different ordering of this shared material, and they differ in the way in which they link the shared material with the more particular traditions of each midrash.

\section{Num. Rab. 13}

In Num. Rab., the interpretation of Song 4:16-5:1 is part of an interpretation of Num 7. Num 7 depicts the sacrifices of the representatives of the tribes on the occasion of the consecration of the sanctuary in the dessert. According to Num. Rab., the representative of Judah represents Israel as a whole in the initial sacrifice, which is read as referring to the general meaning of Israel's cult. This interpretation of the first sacrifices allows for an interpretation of the sacrifices of the representatives of the other tribes as illustrating different deserving ways of life, ${ }^{8}$ which each parallel Israel's

8 One of them is once again the cult. 
sacrifice and are considered to be of equal value.

The interpretation of Song 4:16-5:1 is part of the interpretation of Judah's initial sacrifice:

\begin{tabular}{|c|c|}
\hline \multicolumn{2}{|l|}{ Num. Rab. 13} \\
\hline \multicolumn{2}{|l|}{ Num 7:12 } \\
\hline \multicolumn{2}{|l|}{ I) } \\
\hline Song 4:16 & שלמים \& עולות (ab); the sanctuary (c); the spices (d); the invitation of the \\
\hline Song 5:1 & $\begin{array}{l}\text { the entry of the Shekhinah (a); spices (b) sacrifices (cd); Moses \& Aaron; } \\
\text { Israel (e) }\end{array}$ \\
\hline \multicolumn{2}{|l|}{ II) } \\
\hline Song 4:16ab & the offerings of the children of Noah \\
\hline Song $4: 16 \mathrm{~cd}$ & $\begin{array}{l}\text { the reconciliation of the winds and the meal of the righteous in the Garden } \\
\text { of Eden in the future }\end{array}$ \\
\hline Song 4:16ef; 5:1 & Israel becoming God's bride in exile \\
\hline Song 5:1b-e & the exile $<->$ the Garden of Eden in the time to come \\
\hline III) & \\
\hline Song 4:16ab & שלמים \& עולות \\
\hline Song 4:16c & sanctuary and bride chamber \\
\hline Song 4:16d & spices \\
\hline Song 4:16e; $5: 1 \mathrm{a}$ & $\begin{array}{l}\text { the groom enters the bride's chamber only after the bride's consent; } \\
\text { mashal of the queen who, after having been dismissed, agrees to return to } \\
\text { her husband only after receiving a gift }\end{array}$ \\
\hline Song 4:16ef; 5:1a & $\begin{array}{l}\text { the invitation of the Shekhinah (e); the sacrifices (f); the entry of the } \\
\text { Shekhinah }\end{array}$ \\
\hline Song 4:16e; 5:1a & $\begin{array}{l}\text { mashal of the king having already entered his palace when his people cry } \\
\text { for him }\end{array}$ \\
\hline Song 5:1a & the ascent and descent of the Shekhinah \\
\hline Song 5:1bcd & the spices $(b)$; the sacrifices $(c d)$ \\
\hline Song 5:1e & $\begin{array}{l}\text { Moses \& Aaron - Nadab \& Abihu; mashal of the king's banquet; the } \\
\text { acceptance of the princes' illegitimate sacrifices }\end{array}$ \\
\hline
\end{tabular}

The passage is interpreted three times in succession. The first passage relates the garden to the sanctuary. Each subsection of the two verses is related to a component of or participant in the cult. The second passage identifies the garden of the Song with the Garden of Eden as Israel's dwelling place in an eschatological future on the one hand and with the exile as the counter-horizon of this future dwelling place and as the location of Israel's probation on the other. The third passage once again focuses on the identification of the garden with the sanctuary. In the third, the dialogue structure of 
the two verses is taken into account to a far greater extent than in the two preceding. The motif of the groom only entering the bride's chamber with the bride's consent is illustrated by another version of the mashal about the queen who, after having been dismissed by her husband, agrees to return to him only after receiving proof of his goodwill, which is this time followed by a lengthy explanation:

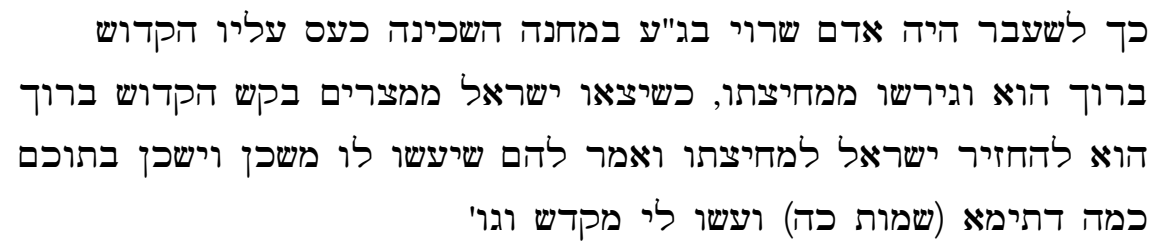

(Bar'Ilan University [ed.], Responsa Project. Version 22+, Tel Aviv 2014.)

So formerly Adam lived in the Garden of Eden in the camp of the Shekhinah. The Holy One, blessed be He, was angry with him and he banished him from his partition. As when Israel left Egypt, the Holy One, blessed be $\mathrm{He}$, wished to restore Israel to his partition and said to them to make for him a Tabernacle, and he would live among them; as it is said: "And they shall make for me a sanctuary," etc. $($ Exod 25:8)

The queen is doubly represented by Adam and Israel: Israel agreeing to its reconciliation only after God's consent to live in Israel's midst after the construction of the sanctuary answers the repudiation of Adam. The mashal is answered by another mashal, according to which the king has already entered his palace when his people cry for him. ${ }^{9}$

Both meshalim serve as reading instructions for what follows, which emphasizes God's goodwill. The traditional piece on the ascent and descent of the Shekhinah

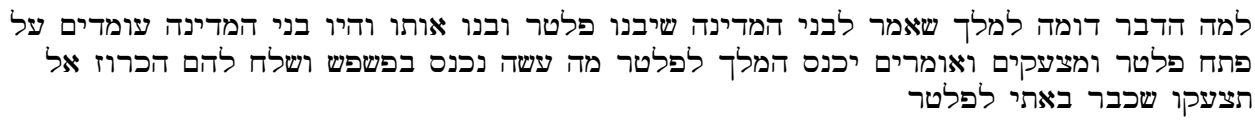

(Bar'Ilan University (ed.), Responsa Project. Version 22+, Tel Aviv 2014.)

"To what can this be compared? To a king who said to the children of a district that they should build a palace. And they built it. And the children of the district stand at the entrance of the palace and they shout and they say: 'Let the king enter the palace!' What did he do? He entered by a wicket and sent to them the proclamation: 'You shall not shout, for I have already come into the palace."” 
closes with the entrance of the Shekhinah into the newly erected sanctuary. Song $5: 1 \mathrm{bc}$ is once more interpreted as referring to different components of and participants in the cult. The interpretation of verse 1 as referring to the components of and participants in the cult establishes a link to the first passage and, with regard to the components of the cult, also to the beginning of the third. The final statement about God accepting the princes' irregular offerings is illustrated with the mashal of the king's banquet.

\section{Pesiq. Rab. 5}

The initial verse of Pesiq. Rab.is Num 7:1. In its biblical context, Num 7:1 is the initial verse of the passage dedicated to the first offering of the representatives of the tribes at the newly erected sanctuary.

\section{Pesiq. Rab. 5}

\section{Num 7:1 halakhah}

constituents of Israel: maintenance of justice, Torah, sanctuary

Num 7:1

constituents of creation: Torah, service at the sanctuary, God's mercies

\begin{tabular}{|c|c|}
\hline Song 4:16ab & the offerings of the sons of Noah \\
\hline Song 4:16c & the spices \\
\hline Song 4:16e & $\begin{array}{l}\text { the Torah; the groom enters the bride chamber only after the bride's } \\
\text { consent }\end{array}$ \\
\hline Song 4:16f & the sacrifices \\
\hline Song 4:16e; $5: 1 \mathrm{a}$ & $\begin{array}{l}\text { mashal of the king having already entered his palace when his } \\
\text { people cry for him - the invitation and the entry of the Shekhinah }\end{array}$ \\
\hline Song 5:1bcd & the spices $(b)$; the sacrifices $(c d)$ \\
\hline Song 5:1bcde & the acceptance of the princes' illegitimate sacrifices \\
\hline Song $4: 16 ; 5: 1$ & sanctuary; bride's chamber \\
\hline
\end{tabular}

Num 7:1 Bezalel and Moses

Num 7:1 the construction of the sanctuary as precondition of the exodus

Num 7:1 the ascent and descent of the Shekhinah - the Shekhinah filling heaven and earth

Num 7:1 ויהי: referring to special moments in Israel's history

Num 7:1 ווי = וידהי: "woes" of those being deprived of privileges by the construction of the sanctuary

Num 7:1 Israel builds the sanctuary - God blesses Israel

Num 7:1 the lower sanctuary meets the upper sanctuary

Num 7:1 Aaron's blessing in this world - God's blessing in the world to come 
An initial halakhah posing the question as to whether someone reading and interpreting a reading passage from the Torah is allowed to depend on a written translation is answered by a strict distinction between written and oral Torah, which, alongside the maintenance of justice and the sanctuary, constitute Israel. Next to the sacrifices at the sanctuary and the mercy of God, the Torah stabilizes creation, which Moses has completed by building the sanctuary.

The subsequent interpretation of Song 4:16-5:1 identifying the garden of the Song with the sanctuary stands at the beginning of a series of interpretations of Num 7:1 focusing on the sanctuary. It starts with a version of the traditional piece on the offerings of the children of Noah in which the final passage, according to which both the עלמים refer to an eschatological future, is missing. The verse's following subsections are interpreted as referring not only to components of the cult but also to the Torah as the teacher of good manners, once more using the example of the groom entering the bride's chamber only after the bride's consent. Song 4:16, 5:1 refer to the entry of Shekhinah into the sanctuary. The groom's answer (יבוא, qatal) in Song 5:1 is illustrated by the mashal, according to which the king has already entered his palace when his people cry for him. The verse's following subsections are interpreted as referring to different components of the cult. The final statement of God accepting the princes' irregular offerings parallels the king's compliance in the mashal. The garden is identified with the sanctuary as Israel's bride's chamber.

The following interpretations of Num 7:1 further focus on the sanctuary. The midrash makes Israel's consent to build the sanctuary a precondition of Israel's exodus. God's presence among his people, made possible by the building of the sanctuary, is illustrated by a fixed textual entity made up of conventional material centering on the ascent and descent of the Shekhinah. The construction of the sanctuary is answered by God blessing Israel. The sanctuary corresponds to its celestial counterpart:

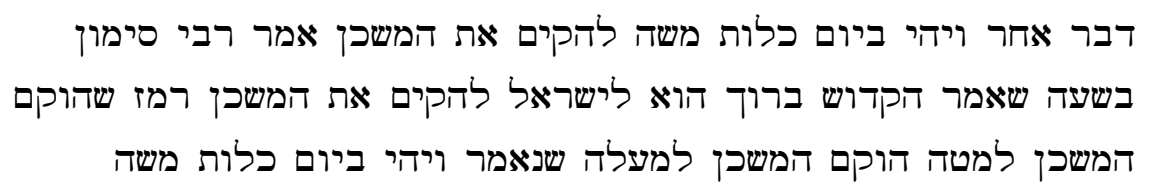




\section{להקים המשכן אין כתיב כאן אלא את המשכן זה המשכן של מעלה}

Bar'Ilan University [ed.], Responsa Project. Version 22+, Tel Aviv 2014.)

Another thing: 'And it came to pass on the day when Moses had finished setting up the tabernacle.' R. Simon said: 'At the time when the Holy One, blessed be He, said to Israel to set up the tabernacle, he hinted that as the tabernacle below was set up, the tabernacle above was set up, as is said: "And it came to pass on the day when Moses had finished," etc. It is not written "setting up the tabernacle [without nota acusativi]" but "the tabernacle" [with nota acusativi]: the tabernacle - that is, the tabernacle from above.'

The literary unit closes with the announcement of the priestly blessing in the present being met by God's blessing in an eschatological future.

\section{Lev. Rab. 9}

Lev. Rab. 9 offers an interpretation of Lev 7:11-12, which conveys further instructions זבח תודה שלמים While modern exegesis understands the (v. 12) as one subspecies of שלמים (Milgrom 1991:412; Staubli 1996:77; Hartley 2000:95.99; Hieke 2014:317), Lev. Rab.takes the זבח תודה in verse 12 as an attribute of the שלמיםin verse 11.

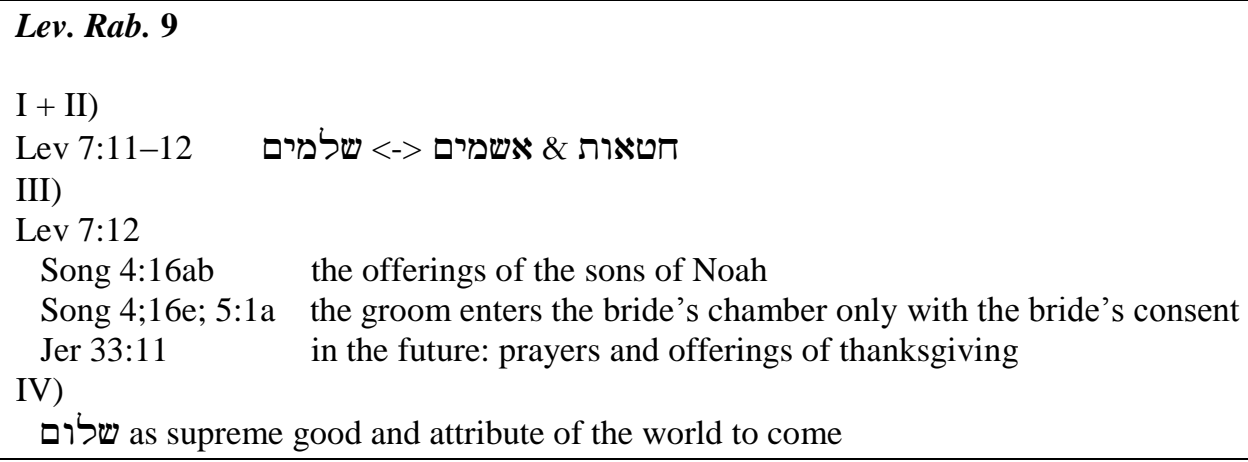

The first two passages that interpret Lev 7:11-12 justify the higher value of the שלמים vis-à-vis the אטאות, with them being offered as זבח תודה and the consequently being offered without any specific reason. A third passage justifies the 
superiority of the שלמים vis-à-vis the עולות using the fixed textual entity made up of conventional material centring on the sacrifices of the children of Noah.

The interpretation of Song 4:16-5:1 forms the greater part of the third passage but uses only a small selection of the material known from other midrashim. It begins with another version of the traditional piece on the offerings of the children of Noah. In contrast to the previously discussed versions of the traditional material, Jethro's ability to offer שלמים is connected not only to a chronology of events that differs from the chronology presented by the biblical text, allowing him to arrive after the Sinai revelation of the Torah, but also to his being a proselyte.

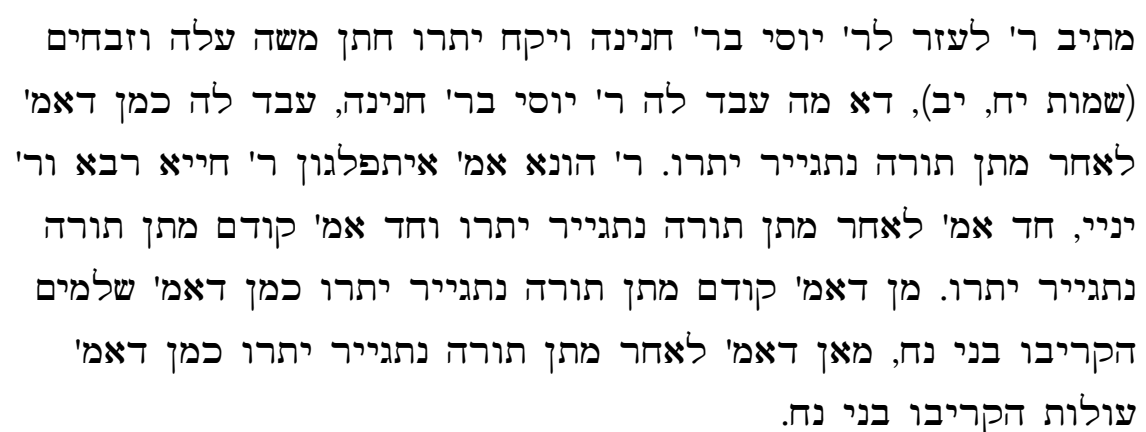

(Margulies 1999)

R. Eleazar answered R. Jose b. Hanina: “And Jethro, Moses' father in law, brought a burnt offering and sacrifices" (Exod 18:12). What did R. Jose b. Hanina make of this? He made of this like that one who says that Jethro became a proselyte after the giving of Torah. R. Huna said: R. Hiyya Raba and R. Jannai differed: One said that Jethro became a proselyte after the giving of Torah, and one said that Jethro became a proselyte before the giving of Torah. The one who said that Jethro became a proselyte before the giving of Torah is like the one who said that the children of Noah offered peace offerings; the one who said that Jethro became a proselyte after the giving of Torah is like the one who said that the children of Noah offered burnt offerings.

The interpretation of Song 4:16-5:1 closes with the statement about the groom entering the bride's chamber only with the bride's consent. 
The motif of marriage creates a transition to an interpretation of Jer 33:11 and the תודה of mirth and gladness, bridegroom and bride that is likewise read as referring to an offering in an eschatological future:

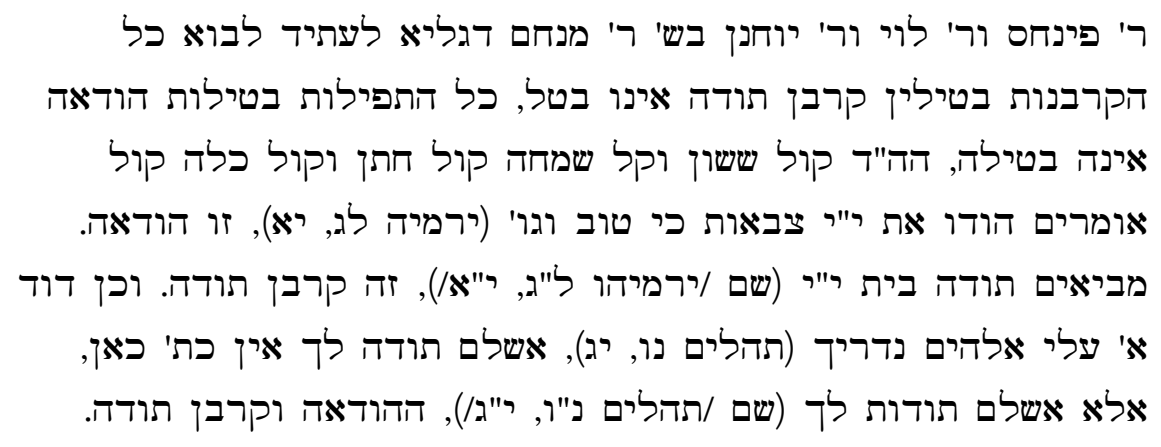

(Margulies 1999)

R. Pinehas and R. Levi and R. Johanan said in the name of R. Menahem of Gallia: In the time to come all sacrifices will be annulled; the sacrifice of thanksgiving will not be annulled. All prayers will be annulled; thanksgiving will not be annulled. This is what is written: 'The voice of rejoicing and the voice of gladness, the voice of the bridegroom and the voice of the bride, the voices of those saying: Give thanks to YHWH of hosts, for he is good,' etc. (Jer 33:11), this is thanksgiving; those bringing [offerings of] thanksgiving to the house of YHWH, this is the sacrifice of thanksgiving. So David says: 'Your vows are upon me, God; I will render thanksgivings to you' (Ps 56:13). It is written here not 'I will render thanksgiving to you' but 'I will render thanksgivings to you': ${ }^{10}$ thanksgiving and the sacrifice of thanksgiving.

In an eschatological future, שלמים no longer stand in opposition to any other sacrifice but rather revoke them. In an eschatological future, which is marked by a harmonious relation between God and mankind, requested sacrifices are of no importance anymore. Only the unrequested שלמים remain.

10 The plural תוזות is understood as having two references. 


\section{CONCLUSION}

By using and recontextualising the discussed material, different midrashim create different hypertexts that organise the quoted material and relate the various components to each other. By doing so, they reconstruct time and space. The following conclusion focuses on the varying understandings of Israel's remembered history as well as of the intended reader's relation to it that underlie the different hypertexts.

Vis-à-vis Song. Rab., Num. Rab. highlights the moment of the construction of the sanctuary and of the first sacrifices there. By emphasizing the time of exile, the midrash inscribes a retarding factor into the chronology of events. By paralleling the initial offering at the sanctuary with other deserving ways of life that are possible even after the destruction of the Temple, Num. Rab. offers its addressees an opportunity to take part in the constitutional moment of the first sacrifice at the desert sanctuary and allows them to inscribe themselves into God's history with his people as established by the midrash.

According to Lev. Rab., the construction of the sanctuary completes the creation of the world. The sacrifices at the sanctuary stabilize the cosmic order. By strengthening the importance of the Torah as another constituent of the order of creation, Lev. Rab., like Num. Rab., allows its addressees to inscribe themselves into the coordinate system created by the midrash. The Torah being a constituent of the world enables the intended reader to take part in Israel's creational role even after the destruction of the temple by studying and interpreting the Torah. Vis-à-vis Num. Rab. and Song. Rab., in Pesiq. Rab. 5 the eschatological future, which is not a substantial part of the coordinate system, is only marginally touched on.

The discussed midrashim create a temporal coordinate system that establishes a temporal distinction between human history and the history of Israel, implying a distinction between mankind and Israel. Lev. Rab. accentuates the midrash's focus on Israel. The possibility of Jethro offering שלמים is understood as depending not only on the chronology of events but also on his conversion to Judaism. Lev. Rab.'s focus on Israel is underlined by its precise image of an eschatological future. In contrast to 
Song. Rab., Lev. Rab. moves the focus from the elimination of any distinction made by the revelation of the Torah to the universality of the condition made possible by the introduction of the Torah and allowing שלמים. In an eschatological future only the unrequested שלמים offerings remain.

The garden of the Song plays a central but shifting role in establishing a coordinate system in space and time: like Song. Rab., Num. Rab. identifies the garden with the Garden of Eden as the location of the initial encounter between God and mankind as well as with the sanctuary as the location of the initial sacrifice and an eschatological future. However, it strongly underlines the location of the sanctuary as the place of the initial encounter between God and Israel and the Garden of Eden as the location of the future encounter between God and Israel in an eschatological future. The garden is also identified with the exile as a counter-horizon to the garden's identification with the location of the encounter between God and Israel in an eschatological future. The exile is the location of Israel's probation.

Pesiq. Rab. identifies the garden of the Song exclusively with the sanctuary as the place of the initial encounter between God and Israel. The traditional piece on the ascent and descent of the Shekhinah, which in Song. Rab. and Num. Rab. is part of the garden's identification with the garden of Eden, is not part of the interpretation of Song 4:16-5:1 in Pesiq. Rab. It is however part of another interpretation of Num 7:1 in its context. Due to the coordinate system of the midrash and its principal statement, it is not read as referring to an eschatological future, which insofar as it plays a role at all is solely connected to the upper sanctuary mirroring the lower one.

Lev. Rab. uses only a small selection of the material known from other midrashim. Within the solely temporal coordinate system that Lev. Rab. creates, Song 4:16 is used to create a temporal distinction between a time before and a time after the giving of Torah and God's established presence in the sanctuary, which already mirrors an eschatological future.

Differing interpretations of Song 4:16-5:1 are linked by their reading of the text as mirroring the varied history between God and Israel. Differing interpretations of Song $4: 16-5: 1$, and especially the understanding of the significance of the garden in the 
Song, are linked with the midrashim's differing interpretations of Israel's remembered history. The way identical material is used by these different midrashim to create their individual hypertexts and make different statements makes them a good example of the handling of traditional material by haggadic rabbinic midrashim.

\section{BIBLIOGRAPHY}

Bakhos, C 2006. Method(ological) matters in the study of Midrash, in Bakhos 2006:161-187. Bakhos, C (ed.) 2006. Current trends in the study of Midrash. Leiden: Brill.

Bar'Ilan University (ed.) 2014. Responsa Project. Version 22+. Tel Aviv: Bar'Ilan University. Bodendorfer, G \& Millard, M (eds) 1998. Bibel und Midrasch. Zur Bedeutung der rabbinischen Exegese für die Bibelwissenschaft. FAT 22. Tübingen: Mohr Siebeck.

Boyarin, D 1990. Intertextuality and the Reading of Midrash. Indianapolis: Bloomington.

Brooks, R \& Collins, J J (eds) 1990. Hebrew Bible or Old Testament? Studying the Bible in Judaism and Christianity. Christianity and Judaism in antiquity 5. Notre Dame, Ind.: University of Notre Dame Press.

Erzberger, J 2010. Kain, Abel und Israel. Die Rezeption von Gen 4:1-16 in rabbinischen Midraschim. BWANT 192. Stuttgart: Kohlhammer.

Goldberg, A 1990. Formen und Funktionen von Schriftauslegung in der frührabbinischen Literatur (1. Jh.v.Chr. bis 8. Jh.n.Chr.), Linguistica Biblica 64:5-22.

Goldberg, A 1985. Form-analysis of midrashic literature as a method of description, in Goldberg and Schlüter 1985:80-95.

Goldberg, A \& Schlüter, M (eds) 1985. Rabbinische Texte als Gegenstand der Auslegung. Texte und Studien zum Antiken Judentum 73. Tübingen: Mohr.

Hartley, J E 2000. Leviticus. Word Biblical Commentary 4. Waco Tex.: Word Books Publ. Hartman, G H \& Budick S (eds) 1986. Midrash and literature. New Haven: Yale Univ. Press. Hieke, T 2014. Levitikus 1-15. HThKAT. Freiburg i.Br.: Herder.

Keel, O 1986. Das Hohelied. Zürcher Bibelkommentare AT 18. Zürich: Theologischer Verlag. Kugel, J L 1986. Two introductions to Midrash, in Hartman \& Budick 1986:77-103.

Kugel, J L 1990. Cain and Abel in Fact and Fable, in Brooks and Collins 1990:167-190. Margulies, M (ed.) 1999. שרדמ ארקיו הבר. 2 Bd. New York: Maxwell Abbell Publ. Fund. Milgrom, J 1991. Leviticus 1-16. The Anchor Bible 3. New York NY: Doubleday.

Neusner, J 1988. Midrash in context. Exegesis in formative Judaism. Brown Judaic Studies 141. Atlanta, Ga.: Scholars Press. 1989. Invitation to Midrash. The workings of rabbinic Bible interpretation. A teaching book. San Francisco: Harper \& Row.

Porton, G G 1985. Understanding rabbinic Midrash. Texts and commentary. The Library of Judaic learning 5. Hoboken N.J.: Ktav Publishing House.

Samely, A 2007. Forms of rabbinic literature and thought. An introduction. New York: Oxford University Press.

Shinan, A \& Zakovitch, Y 1986. Midrash on Scripture and midrash within Scripture, ScrHie 31:257-77.

Staubli, T 1996. Die Bücher Leviticus Numeri. Neuer Stuttgarter Kommentar: Altes Testament 3. Stuttgart: Verlag Katholisches Bibelwerk. 
Stemberger, G 1992. Einleitung in Talmud und Midrasch. München: Beck.

Stern, D 1996. Midrash and theory. Ancient Jewish exegesis and contemporary literary studies. Rethinking Theory. Evanston, Ill: Northwestern University Press.

Teugels, L M 1998. Midrash in the Bible or Midrash on the Bible? Critical remarks about the uncritical use of a term, in Bodendorfer and Millard 1998:43-63.

Schwienhorst-Schönberger, L 2015. Das Hohelied der Liebe. Freiburg i.Br.: Herder.

Wright A G 1967. The literary genre Midrash. New York: Alba House.

Zakovitch, Y 2004. Das Hohelied. HThKAT. Freiburg i.Br.: Herder 